\title{
Faktor agen, pejamu, dan lingkungan kejadian obesitas pada anak usia 5- 6 tahun
}

\author{
Astuti Pavilianingtyas ${ }^{1}$
}

\begin{abstract}
Background: The prevalence of obesity on children is significantly increasing in both of developing and developed countries and has negative impacts on their growth and development. The purpose of this study was to explain the factors that may influence obesity on children aged 5-6 years.

Methode: The case-control study conducted from November 2016 - February 2017 in 7 Kindergartens and Elementary Schools in Tlogosari Kulon Village, Semarang to 88 students and their mother as respondents. The sampling method was proporsionate simple random sampling. The data collected using structured interview, questionnaires and supported by indepth interview. Statistical analysis was conducted using multiple regression logistic method by SPSS 13.0.

Results: The results of the study proved that frequency of fast food consumption $\geq 3$ times per week (OR 3,8; 95\%CI 1,316$11,161)^{[1]}$, duration of screen time > 2 hours per day (OR 5,9; 95\% CI 1,422-24,628), having minimum one obesity parent (OR 3,8; 95\% CI 1,197-11,907) as the risk factors of obesity on children aged 5-6 years. Children aged 5-6 years who have ethnic background as Javanesse (OR 0,03; 95\% CI 0,002-0,547) and mother with low-level education (OR 0,18; 95\% CI 0,035-0,95) proved as protective factors of obesity.

Conclusion: The obesity on children age 5-6 years was influenced by frequency of fast food consumption, duration of screen time, parent's obesity, ethnic background and education level of mother. The influence of screen time and ethnic background on obesity in children need to extend as future epidemiological study.
\end{abstract}

Keywords: Children obesity, fast food, screen time, ethnic

\section{ABSTRAK}

Latar belakang: Prevalensi obesitas pada anak meningkat secara signifikan, baik di negara berkembang, maupun negara maju dan berdampak negatif pada perkembangan serta pertumbuhan anak. Penelitian ini bertujuan menjelaskan beberapa faktor yang mempengaruhi kejadian obesitas pada anak usia 5-6 tahun.

Metode: Penelitian kasus-kontrol dilaksanakan dari bulan November 2016-Februari 2017 di 7 TK dan SD di Wilayah Kelurahan Tlogosari Kulon Kota Semarang kepada 88 siswa dan ibunya sebagai responden penelitian. Pengambilan sampel menggunakan metode proporsionate random sampling. Data dikumpulkan melalui wawancara terstruktur, kuesinoner, dan didukung oleh wawancara mendalam. Analisis statistik dilakukan menggunakan regresi logistik berganda oleh SPSS 13.0..

Hasil: Hasil penelitian membuktikan bahwa frekuensi konsumsi fast food $\geq 3$ kali per minggu (OR 3,8; 95\%IK 1,316-11,161), durasi screen time > 2 jam per hari (OR 5,9; 95\%IK 1,422-24,628), dan memiliki minimum satu orang tua obesitas (OR 3,8; 95\%IK 1,197-11,907) merupakan faktor risiko kejadian obesitas anak usia 5-6 tahun. Anak usia 5-6 tahun yang memiliki latar belakang etnis Jawa (OR 0,03; 95\%IK 0,002-0,547) dan ibu dengan tingkat pendidikan rendah (OR 0,03; 95\%IK 0,0020,547), terbukti sebagai faktor protektif kejadian obesitas.

Simpulan: Obesitas pada anak usia 5-6 tahun dipengaruhi oleh faktor frekuensi konsumsi fast food, durasi screen time, dan obesitas orang tua, latar belakang etnis dan tingkat pendidikan ibu. Pengaruh screen time dan latar belakang etnis pada obesitas anak perlu dikembangkan lagi sebagai penelitian epidemiologi ke depan.

Kata kunci: Obesitas anak, fast food, screen time, etnis

\section{PENDAHULUAN}

Obesitas pada anak adalah suatu kondisi akumulasi lemak yang bersifat abnormal dan berlebihan dalam jaringan tubuh. ${ }^{2}$ Prevalensi obesitas pada anak secara signifian meningkat, baik di negara berkembang maupun maju. 1 dari 8 anak di Amerika menderita obesitas dan meningkatkan risiko obesitas ketika mencapai usia dewasa. ${ }^{3}$ Menurut sebuah penelitian, 42,4\% anak di Itali didiagnosa menderita

\footnotetext{
1. Program Studi Magister Epidemiologi Universitas Diponegoro, Semarang (email korespondensi: apavilianingtyas@gmail.com)
}

obesitas. $^{4}$ Tahun 2010, prevalensi obesitas anak mencapai 5,4\% di negara-negara berkembang. ${ }^{5}$

UNICEF pada Tahun 2013 menyatakan bahwa prevalensi obesitas pada anak di Indonesia adalah $12,3 \%$ pada tingkat sedang-berat. ${ }^{6} 14,7 \%$ anak usia 512 tahun di Kota Semarang, Jawa tengah, mengalami obesitas. ${ }^{7}$ Kelurahan dengan prevalensi obesitas anak tertinggi pada tahun 2014 adalah Kelurahan Tlogosari Kulon yaitu $23,93 \% .^{8}$

Genetik, gaya hidup, lingkungan dan kebudayaan mempengaruhi kejadian obesitas pada anak. Faktor-faktor tersebut berhubungan erat dengan regulasi masukan dan keluaran energi pada anak. Kondisi ketidakseimbangan dari regulasi tersebut, 
menghasilkan energi yang berlebihan dan disimpan dalam bentuk trigliserid. ${ }^{1,9}$

Penyimpanan trigliserid yang berlebihan memicu terjadinya perubahan sel lemak melalui dua mekanisme, hipertrofi dan hiperplasi sel. Pada tahap lanjut, sel lemak akan mengalami proliferasi yaitu penambahan jumlah sel lemak dengan ukuran yang lebih besar daripada sel lemak normal. ${ }^{10,11}$

Risiko obesitas pada anak, menurut beberapa penelitian terdahulu, dipengaruhi oleh beberapa factor antara lain, faktor agen, pejamu dan lingkungan. Faktor agen meliputi kebiasaan konsumsi makanan cepat saji, aktivitas fisik yang ringan, dan riwayat pemberian ASI dan MPASI. Faktor pejamu meliputi genetik, riwayat maternal, riwayat periode awal kehidupan anak. Riwayat maternal dan periode awal kehidupan anak yang diperkirakan mempengaruhi terjadinya obesitas pada anak antara lain usia ibu saat megandung dan berat badan lahir. Sedangkan factor lingkungan meliputi tingkat pendapatan dan pengeluaran rumah tangga, tingkat pendidikan ibu dan nilai ibu terhadap status gizi anak.

Pada dekade terakhir, terjadi perubahan gaya hidup baik pada orangtua maupun anak. perubahan ini memicu perubahan faktor penentu obesitas pada anak, sehingga membutuhkan studi yang lebih aktual dan relevan sehingga mampu menyediakan bukti ilmiah yang memadai. Obesitas pada anak terjadi pada tiga masa kritis yaitu tahun pertama kehidupannya, usia 56 tahun, dan masa remaja. Namun, sesuai perkembangan jaman, studi terkait obesitas pada anak usia 5-6 tahun masih sedikit dilakukan, sehingga perlu dilakukan studi obesitas pada anak di usia ini sehingga dapat mengetahui dan membuktikan faktor risikonya yang aktual dan relevan.Tujuan utama penelitian ini adalah untuk menjelaskan pengaruh beberapa faktor agen, pejamu dan lingkungan pada kejadian obesitas anak usia 5-6 tahun.

\section{BAHAN DAN METODE}

Penelitian ini dilaksanakan menggunakan desain penelitian deskriptif analitik bersifat retrospektif dengan pendekatan kasus-kontrol. Populasi pada penelitian ini adalah anak-anak berusia 5-6 tahun di 7 TK dan SD di wilayah Kelurahan Tlogosari Kulon Kota Semarang. Jumlah sampel yang ditentukan dalam penelitian ini adalah 88 anak berusia 5-6 tahun beserta ibunya dengan perbandingan kasus dan kontrol 1:1. Pengambilan sampel dilakukan dengan metode proporsionate simple random sampling.

Variabel dependen adalah status obesitas responden yang diperoleh melalui pengukuran antropometri tinggi dan berat badan. Pengukuran dilakukan dengan menggunakan instrumen timbangan digital merek GEA dengan akurasi 0,1 kg. Sedangkan, tinggi badan diukur menggunakan alat staturemeter $200 \mathrm{~cm}$ dengan akurasi $0,1 \mathrm{~cm}$. Selanjutnya, dilakukan penghitungan Indeks Massa Tubuh (IMT) dan skor-Z IMT/U menggunakan program komputer $W H O$ Anthroplus.

Variabel independen dalam penelitian ini adalah jenis kelamin, latar belakang etnis, tingkat pendidikan ibu, tingkat pengeluaran per kapita, usia ibu saat hamil, riwayat berat badan lahir, durasi mendapat ASI, usia pertama kali mendapat MPASI, frekuensi konsumsi fast food, riwayat paritas, tingkat aktivitas fisik, durasi screen time, memiliki orang tua obesitas, memiliki saudara kandung obesitas, nilai ibu terhadap status gizi anak.

Pengambilan data dilaksanakan dari bulan November 2016 sampai Februari 2017. Pengambilan data dilakukan dengan menggunakan metode wawancara terstruktur kepada responden anak dan ibu untuk menggali informasi terkait identitas responden, latar belakang etnis, kebiasaan konsumsi fast food, riwayat maternal dan periode awal kehidupan anak. Instrumen lain yang digunakan dalam penelitian ini adalah form recall aktivitas fisik selama satu minggu, form recall pengeluaran pangan dan non pangan dalam 1 bulan terakhir, dan form status gizi keluarga.

Data yang telah diperoleh selanjutnya masuk ke dalam tahap pembersihan data (cleaning), koding data, dan tabulasi data. Setelah ditabulasikan ke dalam program komputer SPPS 13.0 untuk selanjutnya dilakukan analisis statistik. Analisis statistik dilakukan melalui tiga tahap yaitu pertama, analisis univariat untuk mengetahui gambaran karakteristik responden. Kedua, analisis bivariat menggunakan metode Chisquare dengan tingkat kepercayaan 95\%. Tujuan analisis bivariat adalah untuk mengetahui hubungan antara variabel dependen dengan masing-masing variabel independen. Selain itu, analisis bivariat digunakan untuk menentukan variabel yang memenuhi syarat untuk analisis multivariat, yaitu nilai-p $<0,25$.

Ketiga, analisis multivariat menggunakan uji regresi logistik berganda (multiple regression logistic). Analisis multivariat bertujuan untuk mengetahui besarnya pengaruh variabel independen terhadap variabel dependen. Analisis multivariate juga merupakan salah satu cara untuk melakukan pengontrolan terhadap adanya kemungkinan pengaruh konfonding terhadap hubungan variabel dependen dan independen. 
HASIL

Karakteristik subjek penelitian dapat dilihat pada Tabel 1. Rerata skor-Z IMT/U responden pada kelompok kasus adalah 2,6 $\pm 0,7$ SD berkisar antara $2,0-5,4$ SD. Sedangkan pada kelompok kontrol berkisar antara $-1,9-0,9$ dengan rerata $-0,2 \pm 0,7$.

Tabel 1. Karakteristik Subjek Penelitian

\begin{tabular}{lcccccc}
\hline Variabel & \multicolumn{3}{c}{ Kasus $(\mathbf{n = 4 4 )}$} & \multicolumn{3}{c}{ Kontrol $(\mathbf{n = 4 4 )}$} \\
\cline { 2 - 7 } & Mean \pm SD & minimal & maksimal & Mean \pm SD & minimal & maksimal \\
\hline Berat badan $(\mathrm{kg})$ & $28,9 \pm 5,5$ & 15 & 46,30 & $20,2 \pm 3,4$ & 14 & 28,90 \\
Tinggi badan (cm) & $117,5 \pm 8,9$ & 88 & 130 & $115,5 \pm 7,9$ & 95 & 131,10 \\
IMT & $20,7 \pm 2,2$ & 18,5 & 30,6 & $15,0 \pm 0,9$ & 13,1 & 17 \\
Z skor IMT/U (SD) & $2,6 \pm 0,7$ & 2,0 & 5,4 & $-0,2 \pm 0,7$ & $-1,9$ & 0,9 \\
Pengeluaran perkapita & $933.058 \pm$ & 181.071 & 2.794 & $837.724 \pm$ & 228.733 & 5.067 \\
& 526.7 & & & 735.7 & & \\
\hline
\end{tabular}

Rerata pengeluaran perkapita pada kelompok kasus lebih besar daripada kelompok kontrol. Rerata pengeluaran per kapita pada kelompok kasus adalah Rp $933.058 \pm$ Rp 526.7 Sedangkan pada kelompok kontrol, rerata pengeluaran per kapita Rp $837.724 \pm$ Rp 735.7.

Berdasarkan hasil analisis bivariat didapatkan lima variabel independen yang terbukti memiliki hubungan dengan variabel dependen, yaitu latar belakang etnis, frekuensi konsumsi fast food, tingkat aktivitas fisik, durasi screen time, dan memiliki orang tua obesitas. Analisis multivariat pada penelitian ini dilakukan dengan analisis regresi logistik dengan metode Backward:Likelihood Ratio pada tingkat kepercayaan 95\%. Semua variabel kandidat dimasukkan dalam analisis dimulai dari variabel kandidat dengan nilai-p yang paling kecil (bermakna).

Hasil analisis multivariat menunjukkan bahwa ada 5 variabel yang memiliki pengaruh yang signifikan secara statistik dengan kejadian obesitas pada anak usia 5-6 tahun, yang ditunjukkan dengan nilai $\mathrm{p}<0,05$, yaitu frekuensi konsumsi fast food $\geq 3$ kali per minggu, durasi screen time $>2$ jam per hari, latar belakang etnis Jawa, memiliki minimal satu orang tua obesitas, dan tingkat pendidikan ibu rendah.

Tabel 3. Faktor Risiko Obesitas pada usia 5-6 tahun

\begin{tabular}{lccccc}
\hline \multicolumn{1}{c}{ Variabel independen } & $\begin{array}{c}\text { Kasus } \\
(\mathbf{n} / \%)\end{array}$ & $\begin{array}{c}\text { Kontrol } \\
(\mathbf{n} / \%)\end{array}$ & Nilai-p & OR & $\mathbf{9 5 \%}$ CI \\
\hline Frekuensi konsumsi fast food $\geq 3$ kali per minggu & $31 / 70,5$ & $18 / 40,9$ & $0,005^{* *}$ & 3,4 & $1,42-8,33$ \\
Tingkat aktivitas fisik ringan (PAL < 1,55) & $38 / 86,4$ & $35 / 79,5$ & $0,017^{* *}$ & 4,6 & $1,17-17,68$ \\
Durasi screen time > 2 jam per hari & $15 / 34,1$ & $6 / 13,6$ & $0,023^{* *}$ & 3,3 & $1,13-9,48$ \\
Latar belakang etnis Jawa & $38 / 86,4$ & $43 / 97,7$ & $0,039^{* *}$ & 0,2 & $0,01-1,27$ \\
Memiliki minimal satu orang tua obesitas & $19 / 43,2$ & $10 / 22,7$ & $0,040^{* *}$ & 2,6 & $1,02-6,50$ \\
& & & & & \\
& $5 / 11,4$ & $11 / 25$ & $0,094^{*}$ & 0,4 & $0,12-1,22$ \\
Tingkat pendidikan ibu rendah & $14 / 31,8$ & $21 / 47,7$ & $0,126^{*}$ & 0,5 & $0,21-1,21$ \\
Usia ibu saat hamil < 25 atau > 40 tahun & $4 / 9,1$ & $1 / 2,3$ & $0,154^{*}$ & 4,3 & $0,46-40,11$ \\
Memiliki minimal satu saudara kandung obesitas & $24 / 54,5$ & $18 / 40,9$ & $0,200^{*}$ & 1,7 & $0,74-4,03$ \\
Jenis kelamin laki-laki & $0 / 0$ & $1 / 2,3$ & $0,237^{+}$ & - & - \\
Berat badan lahir < 2500 atau > 4000 gram & & & & & \\
& $20 / 45,5$ & $24 / 54,5$ & 0,393 & 0,7 & $0,30-1,60$ \\
Nilai ibu terhadap status gizi anak negative & $38 / 86,4$ & $35 / 79,5$ & 0,394 & 1,6 & $0,52-5,04$ \\
Tingkat pengeluaran per kapita rendah & $38 / 86,4$ & $35 / 79,5$ & 0,394 & 1,6 & $0,52-5,04$ \\
Riwayat paritas nullipara/primipara & $16 / 36,4$ & $18 / 40,9$ & 0,661 & 0,8 & $0,35-1,94$ \\
Usia pertama MPASI $\geq$ bulan & $12 / 27,3$ & $11 / 25$ & 0,808 & 1,1 & $0,43-2,91$ \\
Lama mendapat ASI $\geq 6$ bulan
\end{tabular}

*: Variabel yang menjadi kandidat untuk analisis multivariat

**: Variabel yang memiliki hubungan dengan kejadian obesitas pada anak 5-6 tahun dan sekaligus merupakan kandidat untuk analisis multivariate

†: Variabel tidak valid secara statistic sehingga dieliminasi dari penghitungan statistik 
Model akhir analisis multivariate menunjukkan bahwa ada lima variabel yang terbukti memiliki pengaruh signifikan terhadap kejadian obesitas pada anak usia 5-6 tahun yang ditunjukkan dengan nilai-p < 0,05 . Variabel-variabel tersebut adalah frekuensi konsumsi fast food $\geq 3$ kali per minggu, durasi screen time > 2 jam per hari, latar belakang etnis Jawa, memiliki minimal 1 orang tua obesitas, dan tingkat pendidikan ibu rendah.

Tabel 4. Model Akhir Analisis Multivariat

\begin{tabular}{lllll}
\hline \multicolumn{1}{c}{ Variabel } & Nilai B & \multicolumn{1}{c}{ Nilai-p } & \multicolumn{1}{c}{ OR } & \multicolumn{1}{c}{ 95\% CI } \\
\hline Frekuensi konsumsi fast food $\geq 3$ kali per minggu & 1,343 & 0,014 & 3,8 & $1,316-11,161$ \\
Durasi screen time $>$ 2 jam per hari & 1,778 & 0,015 & 5,9 & $1,422-24,628$ \\
Latar belakang etnis Jawa & $-3,390$ & 0,017 & 0,03 & $0,002-0,547$ \\
Memiliki minimal satu orang tua obesitas & 1,328 & 0,023 & 3,7 & $1,196-11,907$ \\
Tingkat pendidikan ibu rendah & $-1,695$ & 0,044 & 0,2 & $0,035-0,952$ \\
Jenis kelamin laki-laki & 0,985 & 0,083 & 2,7 & $0,881-8,144$ \\
Tingkat aktivitas fisik rendah & 1,621 & 0,084 & 5,1 & $0,805-31,750$ \\
\hline
\end{tabular}

Tabel 5. Probability Event berdasarkan Jumlah Faktor Risiko dan Protektif yang Dimiliki

\begin{tabular}{|c|c|c|}
\hline Jumlah & Faktor Risiko & Probabilitas $(\%)$ \\
\hline \multirow{3}{*}{1 faktor risiko } & Frekuensi konsumsi fast food $\geq 3$ kali per minggu & $11,4 \%$ \\
\hline & Durasi screen time $>2$ jam per hari & $16,6 \%$ \\
\hline & Memiliki minimal satu orang tua obesitas & $11,3 \%$ \\
\hline \multirow{3}{*}{2 faktor risiko } & $\begin{array}{l}\text { Frekuensi konsumsi fast food } \geq 3 \text { kali per minggu }+ \\
\text { Durasi screen time }>2 \text { jam per hari }\end{array}$ & $95,8 \%$ \\
\hline & $\begin{array}{l}\text { Frekuensi konsumsi fast food } \geq 3 \text { kali per minggu+ } \\
\text { Memiliki minimal satu orang tua obesitas }\end{array}$ & $93,6 \%$ \\
\hline & $\begin{array}{l}\text { Durasi screen time }>2 \text { jam per hari+ Memiliki } \\
\text { minimal satu orang tua obesitas }\end{array}$ & $95,7 \%$ \\
\hline 3 faktor risiko & $\begin{array}{l}\text { Frekuensi konsumsi fast food } \geq 3 \text { kali per minggu }+ \\
\text { durasi screen time }>2 \text { jam per hari }+ \text { memiliki minimal } \\
\text { satu orang tua obesitas }\end{array}$ & $74,1 \%$ \\
\hline \multirow[b]{2}{*}{1 faktor protektif } & Latar belakang etnis Jawa & $0,11 \%$ \\
\hline & Tingkat pendidikan ibu rendah & $0,61 \%$ \\
\hline 2 faktor protektif & $\begin{array}{l}\text { Latar belakang etnis Jawa + tingkat pendidikan ibu } \\
\text { rendah }\end{array}$ & $0,02 \%$ \\
\hline
\end{tabular}

Variabel frekuensi konsumsi fast food $\geq 3$ kali per minggu terbukti sebagai faktor risiko kejadian obesitas anak usia 5-6 tahun dengan OR 3,8. Hal ini berarti bahwa anak usia 5-6 tahun yang memiliki frekuensi konsumsi fast food $\geq 3$ kali per minggu memiliki risiko mengalami obesitas 3,8 kali lebih besar dibanding yang memiliki frekuensi konsumsi fast food $<3$ kali per minggu.

Variabel durasi screen time juga terbukti sebagai faktor risiko kejadian obesitas pada anak usia
5-6 tahun. Anak usia 5-6 tahun yang memiliki durasi screen time > 2 jam per hari memiliki risiko mengalami obesitas 5,9 kali lebih besar dibandingkan yang memiliki durasi screen time $\leq 2$ jam per hari.

Variabel latar belakang etnis Jawa terbukti sebagai faktor protektif kejadian obesitas pada anak usia 5-6 tahun (OR 0,03). Hal ini berarti bahwa anak usia 5-6 tahun dengan latar belakang etnis Jawa memiliki risiko mengalami obesitas sebesar 0,03 kali 
lebih besar dibanding yang memiliki latar belakang etnis Jawa.

Variabel memiliki minimal satu orang tua yang mengalami obesitas terbuti sebagai faktor risiko kejadian obesitas pada anak usia 5-6 tahun dengan OR 3,8. Hal ini berarti bahwa anak usia 5-6 tahun dan memiliki minimal satu orang tua yang obesitas berisiko mengalami obesitas 3,7 kali lebih besar dibandingkan yang tidak memiliki orang tua obesitas.

Variabel tingkat pendidikan ibu rendah terbukti sebagai faktor protektif kejadian obesitas pada anak usia 5-6 tahun dengan OR 0,18. Hal ini berarti bahwa anak usia 5-6 tahun yang memiliki ibu dengan tingkat pendidikan rendah memiliki risiko mengalami obesitas 0,18 kali lebih besar dibandingkan anak yang memiliki ibu dengan tingkat pendidikan tinggi.

Hasil penghitungan probabilitas konsumsi fast food $>3$ kali per minggu, durasi screen time $>2$ jam per hari, memiliki minimal satu orang tua yang obesitas, latar belakang etnis Jawa, dan ibu dengan tingkat pendidikan yang rendah berpeluang mengalami obesitas sebesar 1,8\% tanpa dipengaruhi faktor lainnya. Penghitungan probability event (peluang kejadian) untuk setiap kemungkinan faktor risiko dan protektif dapat dilihat dalam Tabel 5. Probabilitas paling tinggi diperoleh pada anak usia 5-6 tahun yang hanya memiliki 2 faktor risiko yaitu frekuensi konsumsi fast food $\geq 3$ kali per minggu dan durasi screen time $>2$ jam per hari. Probabilitas yang paling rendah diperoleh pada anak usia 5-6 tahun yang memiliki dua faktor protektif yaitu latar belakang etnis Jawa dan tingkat pendidikan ibu rendah.

\section{PEMBAHASAN}

Frekuensi konsumsi fast food $>3$ kali per minggu, durasi screen time merupakan faktor risiko terbukti dalam penelitian ini. Keduanya identik dengan gaya hidup moderen (sedentary life). Fast food merupakan makanan yang tinggi kandungan garam, gula dan karbohidrat kompleks, serta memiliki kandungan serat dan zat gizi yang rendah. Makanan jenis ini meningkatkan risiko obesitas bahkan Diabetes Mellitus tipe-2 pada anak. ${ }^{14}$

Iklan televisi memyebabkan anak-anak lebih cepat mengenal dan terkesan dengan makanan cepat saji yang disajikan. Selain itu, ketersediaan dan tampilan bahan makanan di dalam rumah juga menentukan pilihan anak untuk mengkonsumsi fast food atau tidak. ${ }^{15}$ Hasil penelitian ini senada dengan dua penelitian terdahulu bahwa mengkonsumsi fast food minimal 3 kali dalam seminggu berisiko 3,2 kali lebih besar mengalami gizi lebih dan obesitas. ${ }^{16,17}$ Konsumsi makanan anak di jaman sekarang ini sudah jauh dari kesukaan akan makanan jenis sayuran dan buah. Anak-anak cenderung menyukai makanan fast food atau cepat saji, makanan berasa, dan minuman ringan. Makanan jenis ini merupakan makanan tinggi kalori dan lemak, yang mempercepat terjadinya obesitas pada usia anak. ${ }^{18}$

Peran orang tua dalam mengajari anak untuk membatasi konsumsi fast food hanya untuk acaraacara yang special, seperti ulang tahun. Namun, pada hari-hari biasanya, konsumsi fast food dapat digantikan dengan konsumsi bahan makanan yang lebih sehat dan hasil olahan sendiri. ${ }^{19}$

Durasi screen time merupakan waktu yang dihabiskan seseorang melakukan aktivitas di depan layar, baik itu televisi, komputer, telepon genggam, maupun tablet. Hasil penelitian ini senada dengan sebuah studi di Amerika bahwa anak yang menghabiskan banyak waktu di depan layar dapat menderita obesitas yang berhubungan juga dengan inaktivitas selama berada di depan layar. ${ }^{20}$ Anak yang menghabiskan waktu bermain gadget $>2$ jam per hari memiliki risiko 1,57 kali megalami obesitas sesuai dengan hasil penelitian di Jakarta Timur pada tahun $2013 .^{21}$

Kebiasaan ada di depan layar juga meningkatkan keinginan anak untuk ngemil sehingga asupan kalori juga meningkat, sedangkan aktivitas untuk membakar kelebihan kalori tidak ada. ${ }^{18}$ Intensitas anak di depan layar kaca dapat dipengaruhi oleh perilaku screen time orang tua, lingkungan rumah yang memungkinkan melakukan kebiassan ini, dan adanya peraturan atau batasan yang ditetapkan orang tua tentang aktivitas screen time. ${ }^{22}$

Hasil analisis statistik menyatakan bahwa anak yang memiliki orang tua obesitas adalah faktor risiko kejadian terjadinya obesitas di usia 5-6 tahun. Sebuah hasil penelitian menemukan anak dengan orang tua yang kelebihan berat badan berpeluang mengalami gizi lebih sebesar $48 \%{ }^{23}$ Karakteristik orang tua dengan riwayat obesitas berpengaruh pada sifat genetik dan perilaku konsumsi makanan di dalam keluarga. ${ }^{24,25}$

Latar belakang etnis Jawa merupakan variabel yang terbukti sebagai faktor protektif pada kejadian obesitas pada anak usia 5-6 tahun. Etnis atau suku merupakan bagian dari faktor lingkungan sosial dan budaya yang berpengaruh pada aspek biologi dan perilaku dalam proses pemeliharaan kesehatan seseorang, termasuk kesehatan anak. Latar belakang budaya etnis atau suku juga mempengaruhi sistem kepercayaan, prinsip, dan perilaku seseorang. Menurut Peter Davis, seorang ilmuwan kesehatan masyarakat dari Selandia Baru, kelompok faktor budaya yang dapat berupa kepercayaan, praktik atau gaya hidup, biasanya diwujudkan dalam bentuk pola konsumsi makanan atau diet, yang dapat menjadi faktor kunci terkait kondisi kesehatan nutrisi dan pencernaan. ${ }^{26}$ Kebudayaan membentuk suatu persepsi gambaran 
tubuh yang mempengaruhi orang tua untuk menentukan strategi atau keputusan berkaitan dengan pola kebiasaan makan dan jumlah makanan yang tepat bagi anaknya. ${ }^{27}$

Berdasarkan hasil analisis statistik, tingkat pendidikan ibu yang rendah terbukti sebagai faktor protektif kejadian obesitas pada anak usia 5-6 tahun. Faktor-faktor yang ada pada seorang ibu merupakan salah satu faktor yang pertama mempengaruhi status kesehatan seseorang, utamanya anak. $^{26}$ Tingkat pendidikan ibu yang rendah membawa ibu melakukan praktik pola konsumsi makanan yang lebih tradisional atau sederhana kepada anaknya dibanding ibu yang berpendidikan tinggi yang dapat menyiapkan berbagai jenis makanan. ${ }^{28}$

Penelitian lain mendapati bahwa tingkat pendidikan ibu berpengaruh pada kejadian obesitas anak usia 5-6 tahun. Tingkat pendidikan ibu berpengaruh pada tingkat pengetahuan ibu tentang gizi anak, termasuk pemilihan dan penyediaan jenis makanan yang sehat. Rendahnya tingkat pendidikan ibu cenderung mengarahkan ibu memilih fast food untuk dikonsumsi oleh anak mereka dengan frekuensi tinggi. ${ }^{29}$

\section{SIMPULAN}

Faktor risiko yang terbukti dalam penelitian ini adalah frekuensi konsumsi fast food $\geq 3$ kali per minggu, durasi screen time $>2$ jam per hari, dan memiliki minimal satu orang tua obesitas. Hasil penelitian ini juga menemukan dua faktor protektif terhadap kejadian obesitas anak usia 5-6 tahun yaitu latar belakang etnis Jawa dan tingkat pendidikan ibu rendah

\section{DAFTAR PUSTAKA}

1. D'Amore PJ. Childhood Obesity. LabMedicine [Internet]. 2016 Feb 8. 2006 [diunduh pada Feb 18 2016]; 37(5):[298-305 pp.]. Dari: https://labmed.oxfordjournals.org/content/labmed 137/5/298.full.pdf.

2. WHO. What is overweight and obesity ? Global Strategy on Diet, Physical Activity, and Health. Place. Published: WHO; 2016.

3. CDC. Progress on Childhood Obesity [Website article]. Place. Published: CDC;2013.[dikutip pada 3 Mei 2016]. Dari: http://www.cdc.gov/vitalsigns/childhoodobesity/.

4. Ahrens W, Pigeot I, Pohlabeln H, Henauw SD, Lissner L, Molnár D, et al. Prevalence of overweight and obesity in European children below the age of 10. International Journal of Obesity 3 Mei 2016. 2014; 38.
5. Onis Md, Blössner M, Borghi E. Global prevalence and trends of overweight and obesity among preschool children. Am J Clin nutr. 2010.

6. UNICEF. Statistics At a glance: Indonesia. Place. Published: UNICEF; 2013. [diperbarui 2013 Sep 27; dikutip pada Jan 26 2016]. Dari: http://www.unicef.org/infobycountry/indonesia_s tatistics.html.

7. Budi Santoso ea. Pokok pokok hasil riskesdas Provinsi Jawa Tengah 2103. Internet. Jakarta: Kementrian Kesehatan RI, 2013.

8. Dinas Kesehatan Kota Semarang. Status Gizi Anak per Kelurahan di Kota Semarang. Semarang2014.

9. Nelson WE, editor. Ilmu Kesehatan Anak Nelson. 15 ed. Jakarta: EGC; 1999.

10. Ayer J, Charakida M, Deanfield JE, Celermajer DS. Adiposopathy. In: F1.Large, editor. JPG2015.

11. Soetjiningsih. Tumbuh Kembang Anak. Jakarta: EGC; 1995.

12. Karaolis-Danckert N, Buyken AE, Kulig M, Kroke A, Forster J, Kamin W, et al. How preand postnatal risk factors modify the effect of rapid weight gain in infancy and early childhood on subsequent fat mass development: results from the Multicenter Allergy Study. Am J Clin Nutr 29 Feb 2016.

13. Moira APd, Power C, Li L. Changing influences on childhood obesity: a study of 2 generations of the 1958 British Birth Cohort. American Journal of Epidemiology

14. Healthy food for school-age children: the five food groups Place. Published: Raising Children Network; 2016.

15. Campbell KJ, Hesketh DACD. Australian parent's views on their 5-6-year0old children's food chioices. Health Promotion International

.16. Suharsa H, Sahnaz. Status gizi lebih dan faktorfaktor lain yang berhubungan pada siswa sekolah dasar Islam Tirtayasa kelas IV dan V di Kota Serang Tahun 2014. Jurnal Lingkar Widyaiswara 7 Okt 2016.

17. Badjeber F, Kapantouw NH, Punuh M. Konsumsi fast food sebagai faktor risiko terjadinya gizi lebih pada siswa SD Negeri 11 Manado

18. Nurmalina R, Valley B. Pencegahan dan Manajemen Obesitas: Panduan untuk Keluarga. Jakarta: PT Elex Media Komputindo; 2011.

19. Serrano E, Powell A. Healthy eating for children ages 2 to 5 years old: a guide for parents and caregivers. Virginia Cooperative Extension [Internet]. 13 Jun 2017. 2013 [diunduh pada 13 Jun 2017].

Dari: 
https://www.pubs.ext.vt.edu/content/dam/pubs_e xt_vt_edu/348/348-150/348-150_pdf.pdf.

20. Subrahmanyam K, Kraut RE, Greenfield PM, Gross EF. The impact of home computer use on children's activities and development. The Future of Children: Children and Computer Technology. 2000;10(2):123-44.

21. Sarah F, Pujonarti SA. Penggunaan gadget, aktifitas fisik, asupan, dan kaitannya dengan overweight pada siswa SD Marsudirini Matraman, Jakarta Timur tahun 201310 Okt 2016. 2013 [diunduh pada 15 Mei 2017 2017].

22. Thompson JL, Sebire SJ, Kesten JM, Zahra J, Edwards M, Solomon-Moore E, et al. How parents perceive screen viewing in their $5-6$ year old child within the context of their own screen viewing time: a mixed-methods study. BMC Public Health [Internet]. 13 Jun 2017. 2017.

23. Priyatna A. Family Fitness: Membahas Topiktopik yang Penting Diketahui Seputar Membangun Keluarga Bugar dan Sehat. Jakarta: PT Elex Media Komputindo; 2011.

24. Permatasari IRI, Mayulu N, Hamel R. Analisis riwayat orang tua sebagai faktor risiko obesitas pada anak SD di Kota Manado. eJournal Keperawatan Universitas Sam Ratulangi Manado. 2013;1(1):1-7.

25. Reilly JJ, Armstrong J, Dorosty AR, Emmett PM, Ness A, Rogers I, et al. Early life risk factors for obesity in childhood: cohort study. BMJ Online First [Internet]. 2005

26. Lapau B, Saifuddin AF. Epidemiologi dan antropologi: Suatu Pendekatan Integratif Mengenai Kesehatan. 1 ed. Jakarta: Kencana, Prenadamedia Group; 2015

27. Dixon B, Pena M-M, Taveras EM. Lifecourse approach to racial/ethnic disparities in childhood obesity. Adv Nutr [Internet]. 11 Jun 2017. 2012

28. Adsera A, Tienda M, editors. The Annals of The American Academy of Political and Social Science: Migrant Youths and Children of Migrants in a Globalized World. USA: Sage; 2013.

29. Poti JM, Duffey KJ, Popkin BM. The association of fast food consumption with poor dietary outcome and obesity among children: is it the fast food or the remainder of diet. Am J Clin 